\title{
An Empirical Study on Monetary Policy and Economic Growth: The case of Indonesia using an ARDL - ECM Approach
}

\author{
Samoon Safiullah, Faculty of Economics, Kandahar University, Kandahar, Afghanistan. Safi2samoon@gmail.com \\ Pashtoon Rahmatullah, Faculty of Economics, Kandahar University, Kandahar, Afghanistan. rpashtoon@hotmail.com \\ Haqbin Naqibullah, Faculty of Economics, Kandahar University, Kandahar, Afghanistan. Haqbeen.afghan@gmail.com \\ Zahid Abdul Ahad, Faculty of Economics, Kandahar University, Kandahar, Afghanistan. Zahid.kdr@gmail.com \\ Mywanwal Zmarai, Faculty of Economics, Kandahar University, Kandahar, Afghanistan. ghamynoori@gmail.com
}

\begin{abstract}
This study explores the role of monetary policy instruments, particularly through the board money supply and inflation, in support of economic growth in Indonesia. The research base on the long-run co-integration approach using the data from 1970 to 2019 . The goal of this study complies with applying the Autoregressive Distributed Lag (ARDL), and Error Correction Model (ECM), for finding out the long-run co-integration approach among dependents and independent variables. The research includes the Augmented Dickey-Fuller (ADF) unit root test for stationary analysis. The ECM results show that inflation plays a significant but negative role in economic growth in Indonesia. On the other hand, the money supply has also inversely related to the country's economic growth but not significant.
\end{abstract}

Keywords:

Economic Growth, Board Money Supply, Inflation Rate, ARDL

JEL Classifications Code: B22, C22, E51, O4

Article Received: 18 October 2020, Revised: 3 November 2020, Accepted: 24 December 2020

\section{INTRODUCTION}

240

Lex ET Scientia. Economics Series $\square$

LESIJ NR. XVII, VOL. 1/2010

THE IMPACT OF MONETARY POLICY

TOWARD

INDONESIAN STOCK MARKET UNDER

INFLATION

TARGETING REGIME

$*$

\section{Abstract}

A high volatility in stock market movement can be influenced by current news both domestic and international economic shocks, including the ongoing global financial crisis that affect Indonesian economy in particular. Based on empirical studies and theories, that monetary policy can be an effective tool in order to stabilize the stock market volatility. Monetary policy can have a significant effect on the movement in stock market. Does it really happen on Indonesian macro economy? This paper investigates the relations between monetary policy by its instruments and stock market movement. Our empirical evidence is based on before and after the adoption of Inflation Targeting Framework, including the period of Asian Crisis (1997) and the Global Financial Crisis (2008). This paper uses a Vector Error Correction Model (VECM) in order to examine the dynamic movement and changes on Indonesian Stock Market as an impact of the changes in monetary policy in terms of Inflation Targeting regime. Utilizing an Impulse Response and Variance Decomposition approach, this paper analyzes the effectiveness of monetary policy toward the stock market performance in order to achieve the stability of stock market and to develop market expectations. These objectives are beneficial to strengthen the credibility of the Central Bank as the monetary authority in terms of the implementation of Inflation Targeting Framework. Furthermore, this paper attempt to assess and evaluate the monetary policy and induce the central Bank to create an optimal policy in the future. 
Keywords: inflation targeting framework, monetary policy, stock market, vector error correction, variance decomposition

\section{Introduction}

Stock market has become one of the main subjects in terms of macroeconomic stability. Since the monetary policy has, an objective to achieve the price stability in terms macro econo The Central Bank's monetary policy regulation is directed at stabilizing and meeting macroeconomic objectives. As the monetary policy is the essential policy of the government by the implementation, the government from one hand, help to fulfill their responsibilities to the society in line with other macroeconomic policies from the other hand it boosts the real economic stability and growth through the policy (Ononugbo, 2012). As monetary policy is one of the most important and credible policies in implementing a nation's economic growth effectively to support market stability and reduce inflation. According to Akujuobi (2011), monetary policy involves measures to maintain liquidity, implemented by a regional central bank, and used as a mechanism for the economic objectives by controlling a central bank 's distribution of capital. Experts, and World Bank, generally feel that active monetary policy means both financial and economic stability and the utilization of investment capital. Monetary policies are used to monitor and influence outcomes such as productivity, exchange rates, inflation and unemployment with a variety of instruments.

Considering the monetary policy instruments, there are existing two primary theoretical debates which are: Wicksellian and Monetarists. In terms of monetarism, the national Bank of a country controls the money supply process so that Friedmaris "The rule to hold the money supply at a low growth rate will more effectively determine optimum inflation and economic growth (Carlin \& Soskice (2006). Whereas central banks have argued that stable growth of money supply would be necessary because a vital relationship between these mentioned economic indicators would result in stable economic growth. The theory of
Wicksellia suggests that currency is endogenous so that the best means of monetary policy is interest rates. Nevertheless, the recent evolution of increasing monetary policy has helped refute the monetarist system, supposing that the interest rate model is the actual performance of central banks (Fontana G. (2007).

Consequently, in many countries, the present monetary strategy framework has adopted the idea of the new conventional macroeconomics. The new macroeconomic model theory is mostly focusing on using short - term interest rates to maintain the stability of prices (Arestis P. (2007; Folawewo \& Osinubi, 2006). Price stability has as a target a compromise on the supply side and an unwillingness to have a long-term effect on true variables of monetary policy (Bean C. (2007; Fontana G. (2009a). However, the presence of theoretical rigidities in the short term implies that policy may momentarily impact real variables. There is no difference in this respect between the developing and the poor or third world countries (Huang \& Wei, 2006). Therefore, in developing countries, central banks are adopting inflation targeting (IT), which is based on new consensus macroeconomy concepts (John \& Udoye, 2018). In the same period in 2005, Indonesia's Central Bank implemented the full inflation targeting system (Goeltom, 2008; Handoyo, 2013; McLeod, 2003). The Bank reports to the public directly the government-specific inflation target, and monetary policy is geared towards this goal. To meet the inflation target, monetary policy is applied with a forward-looking strategy, implying that any adjustment in the monetary policy posture is made after determining that potential inflation trends are on the line with the inflation target set. Monetary policy also operates with democratic transparency and accountability within this system. The monetary policy approach at the operational level is expected to influence the level of the financial markets and, indeed, the deposit and lending levels in the whole banking framework and in other financial institutes as well in the assessment of the interest rate. Eventually, adjustments in those levels can affect production and inflation (Bank 
Indonesia, 2020). As for many other nations, these changes have been reinforced by more accelerated globalization with important implications for fiscal administration and the money-policies transfer process. Indonesia has experienced a range of farreaching systemic changes in all economic sectors since the start of the 1970s.

Extensive research has been conducted with various sample lengths and scale, which provide different results for both developed developing countries in terms of GDP growth monetary policy for theoretical and quantitative analysis. Such as Turkey (Butkiewicz \& Ozdogan, 2013), South Africa (Precious \& Palesa, 2014), Pakistan (Chaudhry et al., 2012; Personal \& Archive, 2011), Sudan (A. Ahmed et al., n.d.), Malaysia (Mohamadpour et al., 2012), Iran (Anaripour, 2011), China (Dong, 2012), Nigeria (Adeolu \& Sunday, 2012; Akujuobi, 2011; Division, n.d.; Nwakoby, 2016a; Nwoko et al., 2016; Ononugbo, 2012), Indonesia (Goeltom, 2008; Semuel, 2015) and Sri Lanka (W. Madurapperuma, 2016). In many parts of the world at present economic growth relies on limited resources and the provision of goods and services to their population. Furthermore, the more successful these and other economic activities in a society become, the more positively they will influence economic development. A measurement of a country's gross domestic product could indicate either high or low economic growth, as Rodrik (2008) Shreds of evidence showing that exchange rates influence (GDP) in a country. The primary index used by the country's Central Bank for calculating inflation rate is the Consumer Price Index (CPI). The time fluctuations in the CPI represent market fluctuations for the packages of goods and services of public usage. Since July 2008, the bundles of goods and services in the CPI basket have been focusing on the 2007 Cost of Living Survey conducted by Statistics Indonesia (BPS). The main categories of which the inflation is being measured is divided into seven expenditure namely: "Food Stuffs, Processed Foods, Beverages and Tobacco, Housing Clothing, Health, Education and Sports and Transportation and Communications" (Bank
Indonesia, 2020). Without fluctuation, lower inflation rate can enhance economic growth by increasing investment. Therefore, the Central Bank of the country successfully managed to maintain low and stable inflation within the $3.5 \pm 1$ percent target region. In the meantime, as another monetary policy variable that plays a curious role in the stabilization of the real value of money, but for the country predictor the exchange rate is most remarkable, which is the amount of the money of a country in other currencies, the economists have long been mindful that poor management of exchange rates could be harmful to economic growth (Razmi et al., 2012). Thus, the Indonesian Bank works effectively to maintain macroeconomic stability, focusing on rupiah stability. Indonesia is among those countries which have a floating free exchange mechanism. The Indonesia's exchange changes are deeply influenced by net exports and capital inflow. Moreover, Over the course of 2018, the rupiah declined by an average of 6.05 percent relative to 2017. The rupiah depreciated by 12.5 percent during this time, touching the lowest level of the US dollar at IDR15,235 (ECONOMIC REPORT ON INDONESIA, 2018). Therefore, as many economic studies have shown, monetary policy instruments can influence growth in a country. Considering these realities and the key role played by money supply in achieving economic growth in a country, this paper is therefore to examine the impacts of inflation rate, board money supply on economic growth in Indonesia through an econometric perspective. For the accomplishment of this research goal, the (ARDL) econometric modern model, based on the Bound Test Approach model for long-term using 49 years data from 1970 to 2019 .

\subsection{The aims of the research:}

1. To find the impact of the inflation rate on the economic growth in Indonesia

2. To examine the relationship between board money supply and the growth rate of Gross Domestic Product in Indonesia 
As poor institutions and underdeveloped financial systems are the most recognizable indicator of many developing countries, based on these characterized indicators, ensure the policies' transmission, communication, and effects differently from developed nations (Sanchez-Fung \& Ghatak, 2006). It inevitably means, though, that the analysis of monetary policy concentrates mainly on economic growth. Recently in different countries, many methodological and theoretical scientific papers were published that explored the effect on economic development of monetary policy. Such studies either have a negative or a positive impact or confirm that no effect on growth in different regions. S. Ahmed \& Mortaza, (2010). During the year 1980 to 2005, They found that there was a long - term co-integration in Bangladesh between inflation and economic growth. The study used models of co - integration and error correction. Hossain et al. (2012), by applying Augmented Dicker-Fuller and PhillipPerron (PP), models the analyses over the period from 1987 until 2010, no co-integrative relations between economic growth and inflation were identified. Regression model had been implemented in Pakistan using data from 1980 to 2009 in monetary policy impacts for gross domestic product. Which were examined by Hameed et al. (2011), they stated that the rate of interest was minor to Pakistan's GDP, although money supply had an enormous impact on Pakistan's GDP.

There was another analysis by Akinjare et al. (2016), using multiple models of regression in the OLS method. Research defined the interest rate, exchange rate, and the supply of money positively promote economic growth in Nigeria. Similar studies in other industrialized economies have also been conducted; as Borys et al. (2009), the research has taken place in the Czech Republic, addressing the effects of monetary policy on grass domestic product. The results of using the VAR model, it has been indicated that currency shock undermines economic growth and price levels. Also, some other authors come to the conclusion that a strong link between monetary policy and economic
growth.(Akujuobi, 2011; Dong, 2012; Effect et al., 2018; Havi \& Enu, 2014; Lut \& Moolio, 2015; Sean, 2019). The others take into account each other's impact on economic growth by various monetary policy instruments. Akujuobi. (2011), he used the data from 1990 to 2011. OLS results elaborated that the average price and labor force had a positive and significant correlation at the same time, the trend was statistically significant, but negatively, while money supply kept supporting the growth. Similarly, Lashkary and Kashani. (2011), they used data from 22 countries between 2004 and 2010; the result realized that interest rate and growth are in a close relationship. The study also notes that interest rate variation in selected sample countries was neutral.

Moreover, another study was in the United States of America Adda et al. (1997), Who has been investigating the co-integration among the real interest rate and growth. Twenty countries were based, and data from 1960 to 1994 were considered. It described the correlation between these variables as significantly negative. In the same context, an analysis described that the interest and economic growth are negatively correlated with each other in Ghana (Mensah \& Okyere, 2015). Fasanya et al. (2013), the authors considered the monetary policy impacts on Nigeria's economic growth were investigated. The time-series data analyzed by Augmented Dickey-Fuller (ADF) and Phillip-Perron (PP) were used in this analysis. The finding showed that monetary policy tools (exchange rate, inflation rate, and external reserve) were the factor which drive growth in the country. Similarly, another study conducted in South Africa focuses on the relation between monetary policy and economic growth, the authors looked at the cause and effect relationship. The study applied (ADF) and (PP) unit root test from 2000 to 2010 was used. The finding confirmed a co-integration over the long-run period was exists among the study variables. Meanwhile, the finding depicts that inflation role was significant while money supply and exchange rate were insignificant (Precious \& Palesa, 2014). 
However, some certain studies find the positive or partial positive of interest rate effect on economic growth (Drobyshevsky, 2017; Hussain \& Malik, 2011). The suggestion of a survey between 20 different countries of inflation and real interest rates in the growth rate was endorsed in a World Bank study of the exclusion of inflation and its effect on economic growth. Their findings show that the interest rate is positive and significantly correlated with growth. However, the mentioned transaction has inverse effects when inflation is included (Chaudhry et al., 2012). In order to prove the argument as mentioned above, another research done by Hariz et al. (2017). They looked to find out that interest harmful or support the growth in Asian countries. The researchers used the data from 20 counties from 2006 to 2015. Based on the convenience sampling method. The results showed that GDP is adversely affected by the interest rate, while FDI is as well by inflation. Research in Indonesia clarified that inflation has not contributed to economic growth (Semuel, Hatane \& Nurina, 2015).

Besides, the studies investigated the monetary policy's exchange rate volatility. Particularly, the rapid appreciation of the exchange rate after monetary tightening and then the incremental depreciation of the local currency is predicted according to uncovered parity of interest rate. Researchers from Lao identified the long - term effect on the gross domestic product. At the same time, the real exchange rates were positively influenced by the long-term money supply, inflation rate, and the interest rate. This result is achieved used the Johnsen Cointegration and Error Correction Model (Srithilat \& Sun, 2017). Another research also was done, which confirmed that interest rate the monetary policy instrument was not significant (Akujuobi, 2011). Meanwhile, Duskobilov.( 2017), research in Uzbekistan that indicated that monetary policy instruments, including the exchange rate, have positively affected economic growth has been analyzed. Similarly, the study conducted by Chaudhry et al. (2012) also focuses on the analysis nexus between economic growth and exchange rate for Pakistan from 1972 to 2010 their work showed the real exchange rate, along with other considered variables is significant to influence the real GDP. According to Lubis et al (2017), their research was to determine the impact of the exchange rate on a gross domestic product in five-member counties of (ASEAN) association. The results showed the real exchange rate had strong positive support for the growth in the five selected countries using the OLS model. In the meantime, the monetary regime is also a major factor for many central banks, and the role of the system is significant in economic development as well. A similar study which found the strong positive support among exchange rate regimes and economic growth with the observation of the data from 74 countries (T. Mohammed et al., 2018). Over the years 1974-2008 Iranian researchers (Nouri, 2011), using the OLS method, the finding described the supply of money and growth have positive link.

Looking at the literature on this topic, some studies attest to the adverse link between the supply of money and growth. As the study by (Fasanya et al., 2013), which focus on growth and money supply, using data from 1975 to 2010 in Nigeria.The result is found out with the help of the ECM model adverse relation between the mentioned variables. This occurred because of that monetary policy implemented in a developing country has been met with external challenges that have not been seen in the developed nations to present, such as fiscal dominance and the handling of currency replacement. This finding is in line with a research paper in this regard has been written in Ghana by (Adusei, 2013) in 1971-2010. The findings elaborated that financial development, including money supply, does not contribute to economic growth.

\section{DATA SOURCE AND METHODOLOGY}

This research strives to analyses the nexus among economic growth and monetary policy instruments, namely, money supply and inflation rate in Indonesia. For this purpose, the Gross Domestic Product (GDP) independent variable and the board money supply (BMS) and inflation rates (INFR), as 
independent variables, have been chosen. The variable full descriptive picture is depicted in the below Table 1 .

Table 1: Variable descriptive detail

\begin{tabular}{|l|l|}
\hline Variables & Descriptive \\
\hline GDP & Gross Domestic Product \\
\hline BMS & Broad Money supply \\
\hline INFR & Inflation Rate \\
\hline
\end{tabular}

\subsection{The Source of Data:}

All the data have been used in this study is a timeseries data; the duration is from 1970 to 2019, which contains 49 years. The data is using entirely from the (World Bank, 2020) development indicators, and for the analysis, the Eviews .10 was used.

\subsection{Estimation methodology:}

As many studies have applied various economic models and methods to explain economic and monetary policy relationships. While in this study, the ARDL approach has been applied which given by (Pesaran et al., 2001), to analyze equilibrium correlation between economic growth as a dependent variable and monetary policy instrument (i.e., BMS \& INFR) as independent variables. Moreover, as considering the theoretical and literature background different module have been applied to examined the same topic includes OLS (Ayyoub et al., 2011; Dong, 2012; Effect et al., 2018; Gul et al., 2012; Hasanov, 2011; Havi \& Enu, 2014; Idris, 2019; Lut \& Moolio, 2015; Najaf, 2016; Nwakoby, 2016b; Onyeagba, 2015) ECM (Hussain \& Malik, 2011; Mallik \& Chowdhury, 2001), VAR (Bernanke et al., 2005; Borys et al., 2009; Division, n.d.; Kamaan \& Nyamongo, 2014; Munir \& Qayyum, 2012; Precious \& Palesa, 2014), Granger Causality and ARDL (Ekong, 2018; A. Hossain, 2005; Mohammed Ershad \& Mahfuzul, 2017; Mugableh, 2018; Personal \& Archive, 2017; Srithilat \& Sun, 2017; Sulaiman \& Migiro, 2014; W. Madurapperuma, 2016). As the ARDL model was chosen because this approach has many benefits. For instance, in comparison with the traditional Johansen test, which utilizes an equating framework, the ARDL test uses a single reduced form of the equation to analyze the mixture of the inputs (Dingela \& Khobai, 2017). Therefore, taking these advantages, the (ARDL) bound testing model and error correction model (ECM) has been applied to co-integration. Then, for unit root and variables stationary evaluation, the Augmented Dickey-Fuller (ADF) is used. To test for the relationships that co-integrate of the long-term relationships among the dependent variable GDP and independent variables BMS and INFT. Based on the studies (Ali Shah et al., 2012; Dingela \& Khobai, 2017; Mugableh, 2018), the equation can be written as follows:

$G D P=f($

BMS,INFR)

Where:

GDP $=$ Gross Domestic Product

BMS = Board Money Supply

INFR = Inflation Rate

As in this paper, the only one variable appears in logarithmic form; therefore, the empirical model can write as below:

$\ln \mathrm{GDP}=\beta 0+\beta 1 \mathrm{BMS}+\beta 2 \mathrm{INFR}+$ $\varepsilon t$

Where:

$\beta 0=$ Intercept

$\beta 1,2, \ldots n=$ Coefficients

$\varepsilon t=$ Erorro term

\subsection{Empirical Analysis}

\subsubsection{Unit Root Tests}

In order to analyze the long-term contributions among the variables, the initial step of the research includes the use of the Augmented Dickey-Fuller (ADF) unit root. 
Table 2: Unit root outcomes

\begin{tabular}{lcccc}
\hline & T-test & Prob. Value $(*)$ & Critical value at 5\% & Result \\
\hline Ln GDP $(* *)$ & -3040897 & 0.0383 & -2.925169 & I $(0)$ \\
\cline { 1 - 3 } BMS $(* *)$ & -3.485110 & 0.0127 & 2.923780 & I $(0)$ \\
\hline INFR $(* *)$ & -4.797710 & 0.0003 & -2923780 & I $(0)$
\end{tabular}

* Depicts significance level for McKinnon critical value, **Regression in first order with the trend and intercept, $* * *$ Regression in first order with intercept, ****Regression in level with the trend and intercept.

The data confirm the suitability for the cointegration of the ARDL-bound test. The result is indicated in Table 2. The statistics for GDP (LnGDP), broad monetary (BMS) supply (BMS), and inflation (INFR) are statistically significant. ADF test shows that all variables, including GDP, BMS, and INFR, are stationary at I (0), where inflation rate and supply of money are stationary at levels.

\subsection{ARDL-Bound Test Approach to Cointegration}

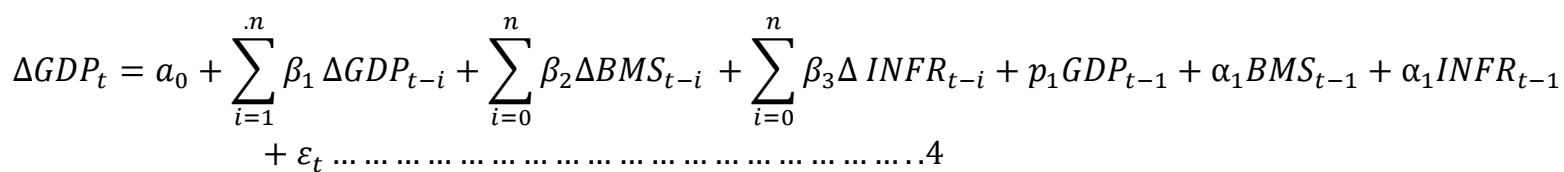

Secondly, if the F-bound test study has a long term relation, $\mathrm{H} 0$ is thus the null hypothesis of a cointegration of the component in equation 4 when $\mathrm{H} 1$ is the alternative. The co-integration of factors is not feasible.

$H 0=\alpha 1=\alpha 2=\alpha 3=\alpha 4=0$ (There is no long - term relationship)

Check against the alternative hypothesis

$H 0 \neq \alpha 1 \neq \alpha 2 \neq \alpha 3 \neq 0$ (No long - term

relationship exists)

Finally, the calculated F-statistic Value of ARDL bound-test $t$ shall be compared with the critical value boundaries upper and lower of 90,95 , or 99 percent suggested by (Pesaran et al., 2001). When the F-statistics value is bigger than the upper bound value (i.e., I (1)), this simply implies the existence of long-term collaboration among variables. From the other side, in case the F-statistic value is lower
After it becomes clear that all the variables had no non - stationary issues, the next step is to consider a long - term relation between economic growth, inflation, and broad money. To determine the longterm relationship between variables, the ARDLbound testing approach and ECM have been used. Following the studies of Ali Shah (2012) Dingela and Khobai, (2017) and later in the paper of Mugableh (2018) to test for the relationships that co-integrate. The first move for designing the model is to calculate GDP (Y) as a dependent variable, for error correction as long as they are built in the following ECM model.

than the lower bound value (i.e., I (0)), This means that co- integration of variables does not exist. Finally, the outcome becomes inconclusive when the calculated value lies in the middle of these two bounds. The F-statistics value is depicted in table 3; the calculated Value (71.51914) is higher than the upper bound value of F-statistic, which is (3.87) at $5 \%$ level of significance.

Consequently, it indicates that the results cointegrate the GDP, board money supply, and inflation rate of the three interrelated factors over a long period. Until determining which variables are integrated, the optimum lag period must be calculated. To order to find the optimal lag length, the Akaike information method is used, and the lowest configuration (AIC) has been introduced; the results are shown in Table 4. As (ECM) is considered appropriate for study, taking into 
account the co-integration test results, which demonstrate the existence of co-integration within economic model variables.

Table 3: F-statistic Bounds Test co-integration Result

\begin{tabular}{lrrrr}
\hline \hline & Value & Signif. & I(0) & I(1) \\
\hline \hline & & & & \\
F-statistic & $\mathbf{7 1 . 5 1 9 1 4}$ & $10 \%$ & 2.63 & 3.35 \\
& & $\mathbf{5 \%}$ & $\mathbf{3 . 1}$ & $\mathbf{3 . 8 7}$ \\
& $2.5 \%$ & 3.55 & 4.38 \\
& & $1 \%$ & 4.13 & 5
\end{tabular}

Table 4: VAR Optimal Lag-length Selection

\begin{tabular}{ccccccc} 
Lag & LogL & LR & FPE & AIC & SC & HQ \\
\hline \hline 0 & -369.2644 & NA & 2146.939 & 16.18541 & 16.30467 & 16.23008 \\
$\mathbf{1}$ & -204.6899 & $300.5274 *$ & $2.481812^{*}$ & $\mathbf{9 . 4 2 1 2 9 9 *}$ & $9.898336^{*}$ & $9.600000^{*}$ \\
2 & -195.7536 & 15.15282 & 2.503240 & 9.424070 & 10.25888 & 9.736796 \\
3 & -187.5141 & 12.89658 & 2.623883 & 9.457136 & 10.64973 & 9.903888 \\
4 & -182.2142 & 7.604257 & 3.163929 & 9.618008 & 11.16838 & 10.19879 \\
\hline \hline
\end{tabular}

AIC: Akaike information criterion, SC: Schwarz information criterion, HQ: Hannan-Quinn criterion

Table 5 shows the long - term co-integration of variables showing that the money supply to Indonesian economies is not contributing to economic growth. Base on the negative coefficient of the supply of money, a unit change would bring about 0.0023 units to decrease in economic growth at $5 \%$ level of significance indicating a negative impact on economic growth. The effect remains insignificant at 5 percent and 0.9073 probability, the impact continues to be insignificant.

Concerning the negative sign of the coefficient that indicates the effect on the economic growth of monetary policies, the model showed that the money supply showed signs contrary to previous theoretical expected conditions. It is worth mentioning that the final study finding is also consistent with the study of (Fasanya et al., 2013; Nwakoby, 2016b), who also found out that money supply was an insignificant tool of monetary policy for Nigerian economic growth. Furthermore, the findings reveal that the inflation rate is negatively correlated with GDP, which indicates that the inflation rate is the dominant monetary policy tool that will decrease economic growth by approximately 0,104880 if the inflation rate increases in one unit. Although the results coincide with the findings of (Shamim Ahmed, 2005; Ayyoub et al., 2011; Chaturvedi et al., 2008; Mamo, 2012; I. Mohammed \& Ehikioya, 2015; Nwakoby, 2016b; Quartey, 2010; Salian, n.d.; State et al., 2012), Which indicates that inflation current rate base on the study data does not promote economic growth in the long- run in Indonesia. Notwithstanding the Keynesian theory, Other economic opinions indicate that moderate inflation boosts economic growth (Mubarik, 2005). Realistically, however, aspirations and inflationary spirals would slowly lead to higher price levels and macroeconomic uncertainty; also the economic growth will also be adversely affected. (Ayyoub et al., 2011). 
Table 5: ARDL Estimation Results

\begin{tabular}{crrrr} 
Variable & Coefficient & Std. Error & t-Statistic & Prob. \\
\hline \hline BMS & -0.002319 & 0.019796 & -0.117152 & 0.9073 \\
INFR & -0.104880 & 0.041644 & -2.518522 & 0.0154 \\
\hline C & 30.22362 & 0.906827 & 33.32897 & 0.0000 \\
\hline \hline EC = LNGDP - $(-0.0023 *$ BMS $-0.1049 *$ INFR +30.2236$)$ & $=$ \\
\hline \hline
\end{tabular}

\subsection{The Error Correction Model (ECM)}

The model is formulated in the following manner, in order to find out the error correction model:

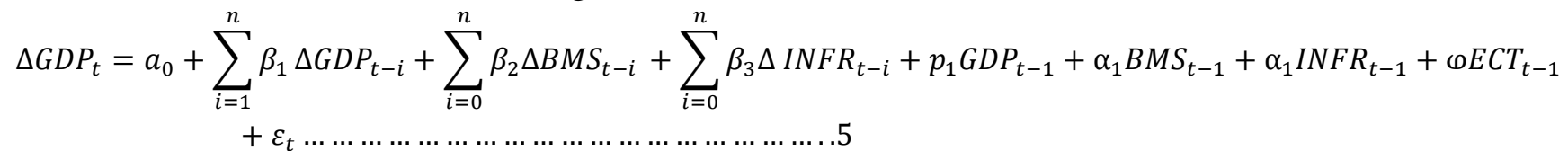

The study examines the long - term influence of the money supply and inflation rate on Indonesia's economic growth. As the data of table 6 proof with the negative ECT (-1), e.g., -0.629894. The model is suitable and shows a long-run co-integration of selected variables but not statistically significant.

Table 6: Error Correction Model (ECM)

\begin{tabular}{crrrr}
\hline \hline Variable & Coefficient & Std. Error & t-Statistic & Prob. \\
\hline \hline C & 0.006089 & 0.030578 & 0.199116 & 0.8431 \\
D(LNGDP(-1)) & 0.880907 & 0.563500 & 1.563276 & 0.1253 \\
D(BMS(-1)) & 0.000403 & 0.000512 & 0.786604 & 0.4358 \\
D(INFR(-1)) & -0.000286 & 0.000606 & -0.471700 & 0.6395 \\
ECT(-1) & -0.629894 & 0.621980 & -1.012722 & 0.3169 \\
\hline
\end{tabular}

\section{STABILITY DIAGNOSTIC AND TESTS}

The ECM model was tested to boost the reliability of this research through specific diagnostic and stability tests. The calculated probability value of the LM serial correlation test from BreuschGodfrey, for example (0.1801), exceeds than $(5 \%$ significance interval), and it demonstrates we understand the pattern without any serial correlation problem. While the white test for heteroskedasticity does not show any proof of heteroskedasticity. Similarly, the calculated probability value (0.1436) of Ramsey RESET tests reveals that no misspecification has been seen in the model.

On the other hand, a normal distribution test's likelihood value indicates the data are usually not transmitted. The findings thus demonstrate that the durability and the value of the model are confirmed by each diagnostic test. However, the normal distribution test shows that the data are not usually passed; these all presented in Table 7.

Table 7: Diagnostic Tests

$\begin{array}{llll}\text { Test } & \text { F-statistics Prob. Value } & \text { Ho } & \text { Decision }\end{array}$




\begin{tabular}{lccll}
\hline Serial Correlation LM & 1.787739 & 0.1801 & No serial correlation & Accept H0 \\
Heteroskedasticity. & 0.058164 & 0.9935 & No heteroscedasticity & Accept H0 \\
Ramsey RESET & 1.490404 & 0.1436 & No specification errors & Accept H0 \\
Normal Distribution & 2012.296 & 0.00000 & No normal distribution & Reject H0 \\
\hline
\end{tabular}

CUSUM and CUSUM square graphic illustrations are shown in figure 1 for the long-term stability tests and short-term transfers of the ARDL Error Corrections pattern. According to Bahmani and Oskooee (2004), if these numbers stay within the vital boundaries of the five percent meaning level, the null hypothesis (e.g., that the regression equation is correctly specified) cannot be rejected. However, considering the case of CUSUM of recursive squares (CUSUMQ), for specific years, the level of significance is above $5 \%$, which in this particular period, structurally faces uncertainty.

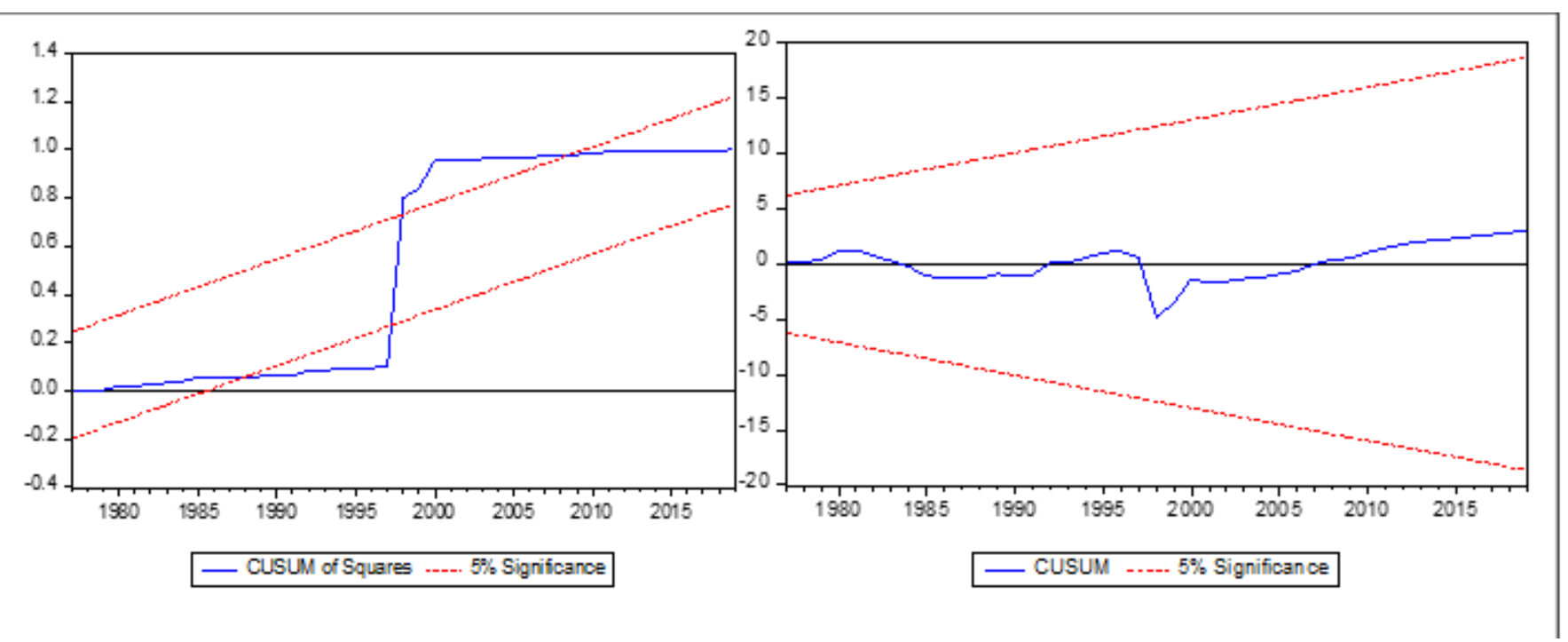

Figure 1 Plots of CUSUM and CUSUMSQ Plots at 5\% level of significance.

\section{CONCLUSION}

The stabilizing position of monetary policy is essential to economic well-being as the study focuses on examining the effects of monetary policy tools in the particular supply of money and inflation rate on economic growth (GDP per capita) in Indonesia using time series data from 1970 to 2019. The paper has implemented the econometric model of ARDL to estimate the long-run relationship between dependent variables and independents. The ARDL co-inclusion study also shows the strong detrimental correlation between Indonesian growth and inflation. Economists remain uncertain about the interrelation between inflation and economic growth. Therefore, further research is needed to show the level of inflation appropriate in order to promote their economic growth through inflation for Indonesian governments or the central Bank. Besides, the correlation between money supply and economic growth has proved to be negative, but not significant while, the result turned out to be the opposite of theory. New research, however, is needed to determine why money supply and economic growth are being adversely affected.

\section{REFERENCES}

[1] Adda, C. D. ', Scorcu, A. E., D'adda Antonello, C., \& Scorcu, E. (1997). Real Interest Rate and Growth: An Empirical Note. http://amsacta.unibo.it/id/eprint/764

[2] Adeolu, M., \& Sunday, J. (2012). Fiscal / Monetary Policy and Economic Growth in Nigeria: A Theoretical Exploration. 1(5), 75-88. 
[3] Adusei, M. (n.d.). Financial Development and Economic Growth: Evidence from Ghana Some of the authors of this publication are also working on these related projects: Board Gender Diversity And The Capital Structure Of Microfinance Institutions View project. In papers.ssrn.com. Retrieved August 10, 2020, from https://www.researchgate.net/publication/2 56061991

[4] Ahmed, A., Studies, S. S.-J. of B., \& 2011, undefined. (n.d.). The long-run relationship between money supply, real GDP, and price level: Empirical evidence from Sudan. Pdfs.Semanticscholar.Org. Retrieved March 15, 2020, from https://pdfs.semanticscholar.org/3d3f/6565 2122cc828deded98393fc2012d2603f8.pdf

[5] Ahmed, S, \& Mortaza, M. (2010). Inflation and economic growth in Bangladesh: 19812005.

https://ideas.repec.org/p/ess/wpaper/id303 3.html

[6] Ahmed, Shamim. (2005). Policy Analysis Unit ( PAU ) Working Paper Series : WP 0604 Inflation and Economic Growth in Bangladesh: 1981-2005 Policy Analysis Unit * ( PAU ) Working Paper Series : WP 0604 Inflation and Economic Growth in Bangladesh : 1981-2005. December.

[7] Akinjare, V., ... A. B.-I., \& 2016, undefined. (n.d.). Monetary Policy and its Effectiveness on Economic Development in

Nigeria.

Eprints.Covenantuniversity.Edu.Ng.

Retrieved April 2, 2020, from http://eprints.covenantuniversity.edu.ng/77 44/

[8] Akujuobi, L. (2011). Monetary Policy and Nigeria's Economic Development. African Research Review, 4(4), 153-161. https://doi.org/10.4314/afrrev.v4i4.69218

[9] Ali Shah, A., Kouser, R., Aamir, M., \& Saba, I. (2012). Empirical Analysis of Long and Short Run Relationship among
Macroeconomic Variables and Karachi Stock Market: An Auto Regressive Distributive Lag (ARDL) Approach RehanaKouser (Corresponding Author). Pakistan Journal of Social Sciences, 32(2), 323-338.

[10] Anaripour, J. T. (2011). Study on relationship between interest rate and economic growth by eviews (2004-2010, Iran). Journal of Basic and Applied Scientific Research, 1(11), 2346-2352. https://doi.org/http://dx.doi.org/10.1016/j.d ental.2011.06.006

[11] Ayyoub, M., Chaudhry, I. S., \& Farooq, F. (2011). Does Inflation Affect Economic Growth? The case of Pakistan. Pakistan Journal of Social Sciences (PJSS), 31(1), 51-64.

http://www.bzu.edu.pk/PJSS/Vol31No120 11/Final_PJSS-31-1-05.pdf

[12] Bernanke, B. S., Boivin, J., \& Eliasz, P. (2005). Measuring the Effects of Monetary Policy. Quarterly Journal of Economics, 120 , 387-422. https://doi.org/10.1162/003355305332745 2

[13] Borys, M. M., Horváth, R., \& Franta, M. (2009). The effects of monetary policy in the Czech Republic: An empirical study. Empirica, 36(4), 419-443. https://doi.org/10.1007/s10663-009-9102$\mathrm{y}$

[14] Butkiewicz, J. L., \& Ozdogan, Z. (2013). Zeliha Özdoğan-Working Paper.

[15] Chaturvedi, V., Kumar, B., \& Dholakia, R. H. (2008). Inter-Relationship Between Economic Growth, Savings and Inflation in Asia Indian Institute of Management Ahmedabad-380 015 India Iima India InterRelationship Between Economic Growth, Savings and Inflation in Asia.

[16] Chaudhry, I. S., Yasmin, Q., \& Farooq, F. (2012). Monetary policy, inflation and economic growth in Pakistan: exploring the co-integration and causality relationships. 
Pakistan Journal of Commerce and Social Sciences, 6(2), 332-347.

[17] Dingela, S., \& Khobai, H. (2017). Dynamic Impact of Money Supply on Economic Growth in South Africa. An ARDL Approach Dynamic Impact Of Money Supply On Economic Growth In South Africa: An Ardl Approach. https://mpra.ub.unimuenchen.de/id/eprint/82539

[18] Division, R. S. (n.d.). Effects of Monetary Policy on the Real Economy of Nigeria : A Disaggregated Analysis. November 2014.

[19] Dong, Z. (2012). Impact of monetary policy on economic growth in China. Advances in Information Sciences and Service Sciences, 4(16), 123-132. https://doi.org/10.4156/AISS.vol4.issue16. 15

[20] Drobyshevsky, S. (2017). The Effect of Interest Rates on Economic Growth Elena Sinelnikova-Muryleva The Effect of Interest Rates on Economic Growth. http://stolypinsky.club/economica-rosta/

[21] Duskobilov, U. (2017). Impact of Economic Regulation through Monetary Policy: Impact Analysis of Monetary Policy Tools on Economic Stability in. $3(5)$, 65-69. https://doi.org/10.18775/ijied.1849-75517020.2015.35.2005

[22] ECONOMIC REPORT ON INDONESIA ISSN 0522-2572 Vision. (2018).

[23] Effect, T., Exchange, O., Force, L., Economic, O., In, G., Kala, G., Masbar, R., \& Syahnur, S. (2018). the Effect of Exchange Rate, Inflation, Capital and Labor Force on Economic Growth in Indonesia. Jurnal Ekonomi Dan Kebijakan Publik Indonesia, 5(1), 35-50.

[24] Ekong, U. M. (2018). Monetary Policy Pass-Through in Nigeria: An ARDL Bound Testing Approach. http://www.aroec.org/ojs/index.php/ARoE c/article/view/60
[25] Fasanya, I. O., Onakoya, A. B., \& Agboluaje, M. A. (2013). Does monetary policy influence economic growth in Nigeria? Asian Economic and Financial Review, 3(5), 635-646.

[26] Folawewo, A. O., \& Osinubi, T. S. (2006). Monetary Policy and Macroeconomic Instability in Nigeria: A Rational Expectation Approach. Journal of Social Sciences, 12(2), 93-100. https://doi.org/10.1080/09718923.2006.11 978375

[27] Fontana G. (2007), "Why Money Matters: Wicksell,... - Google Scholar. (n.d.). Retrieved March 15, 2020, from https://scholar.google.com.my/scholar?hl= en\&as_sdt $=0 \% 2 \mathrm{C} 5 \&$ as_vis $=1 \& \mathrm{q}=$ Fontana + G. $+\% 282007 \% 29 \% 2 \mathrm{C}+$ "Why+Money+ Matters\%3A+Wicksell\%2C+Keynes\%2C

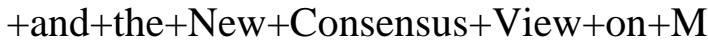
onetary+Policy\%2C"\&btnG=

[28] Goeltom, M. S. (2008). The Transmission Mechanisms of Monetary Policy in Indonesia. BIS Papers, 35(35), 309-332.

[29] Gul, H., Mughal, K., \& Rahim, S. (2012). Linkage between Monetary Instruments and Economic Growth. Journal of Management and Social Sciences, 2(5), 6976.

[30] Hameed, I., Research, A. U.-I. of I. B., \& 2011, undefined. (n.d.). Impact of monetary policy on gross domestic product.

[31] Handoyo, R. D. (2013). The Impact Monetary and Fiscal Policy Shock on Indonesian Stock Market. Prosiding Persidangan Kebangsaan Ekonomi Malaysia Ke VIII 2013, 2, 1022-1036.

[32] Hariz, M., Bin, A., Harswari, N., \& Hamza, S. M. (2017). the Impact of Interest Rate on Economic Development: a Study on Asian Countries. International Journal of Accounting \& Business Management, 5(1), 180-188.

https://doi.org/24924/ijabm/2017.04/v5.iss $1 / 180.188$ 
[33] Hasanov, F. (2011). Relationship Between Inflation and Economic Growth in Azerbaijani Economy: Is There Any Threshold Effect? Asian Journal of Business and Management Sciences, 1(1), $1-11$.

http://www.ajbms.org/articlepdf/ajbms_20 11_1103.pdf

[34] Havi, E. D. K., \& Enu, P. (2014). The Effect of Fiscal Policy and Monetary Policy on Ghana's Economic Growth: Which Policy Is More Potent? Research Academy Of Social Sciences (RASS), 3(2), 61-75.

[35] Hossain, A. (2005). Granger-Causality Between Inflation, Money Growth, Currency Devaluation and Economic Growth in Indonesia, 1951-2002. International Journal of Applied Econometrics and Quantitative Studies, 2(3), 45-68.

[36] Hossain, M., Ghosh, B., World, M. I.-R., \& 2012, undefined. (n.d.). Inflation and economic growth in Bangladesh. Academia.Edu. Retrieved April 1, 2020, from

https://www.academia.edu/download/3230 4485/Inflation_and_economic_growth.PD $\mathrm{F}$

[37] Huang, H., \& Wei, S. J. (2006). Monetary policies for developing countries: The role of institutional quality. Journal of International Economics, 70(1), 239-252. https://doi.org/10.1016/j.jinteco.2005.09.0 01

[38] Hussain, S., \& Malik, S. (2011). Inflation and Economic Growth: Evidence from Pakistan. International Journal of Economics and Finance, 3(5). https://doi.org/10.5539/ijef.v3n5p262

[39] Idris, M. (2019). Monetary Policy and Economic Growth in Developing Countries: Evaluating the Policy Nexus in Nigeria. International Journal of Business and Economics Research, 8(5), 303. https://doi.org/10.11648/j.ijber.20190805. 17
[40] Kamaan, C. K., \& Nyamongo, E. M. (2014). The Effect of Monetary Policy on Economic Growth in Kenya. International Journal of Business and Commerce, 3(8), 11. https://doi.org/10.5539/ibr.v7n12p67

[41] Lashkary, M., \& Kashani, B. H. (2011). The impact of monetary variables on economic growth in Iran: A monetarists' approach. World Applied Sciences Journal, 15(3), 449-456.

[42] Lubis, M. R. G., Karim, N. A.-H. A., Tha, G. P., \& Ramli, N. R. (2017). Exchange Rate Effect on Gross Domestic Product in the Five Founding Members of ASEAN. International Journal of Academic Research in Business and Social Sciences, $7(11)$, 1284-1293. https://doi.org/10.6007/ijarbss/v7-i11/3565

[43] Lut, M., \& Moolio, P. (2015). The Impact of Monetary Policy on Economic Growth in Cambodia. In Journal of Management for Global Sustainable Development (Issue 1). http://www.timesresearchconsultant.com/ wp-content/uploads/2019/05/01-40-63The-Impact-of-Monetary-Policy-onEconomic-Growth-in-Cambodia.pdf

[44] Mallik, G., \& Chowdhury, A. (2001). Inflation and economic growth: evidence from four South Asian countries. AsiaPacific Development Journal, 8(1), 123135.

[45] Mamo, F. T. (2012). Economic Growth and Inflation A panel data analysis. Economics, $1-44$.

[46] McLeod, R. H. (2003). Towards improved monetary policy in Indonesia. Bulletin of Indonesian Economic Studies, 39(3), 303324.

https://doi.org/10.1080/000749103200014 2764

[47] Mensah, A. C., \& Okyere, E. (2015). Real Economic Growth Rate in Ghana: the Impact of Interest Rate, Inflation Rate and Gdp. Global Journal of Research in Business \& Management, 4(1), 206-212. www.gpcpublishing.com 
[48] Mohamadpour, B., Behravan, N., \& Espahbodi, S. (2012). Study of association between monetary policy and GDP: An econometric perspective in Malaysia. Australian Journal of Basic and Applied Sciences, 6(8), 307-315.

[49] Mohammed Ershad, H., \& Mahfuzul, H. (2017). Empirical Analysis of the Relationship between Money Supply and Per Capita GDP Growth Rate in Bangladesh. Journal of Advances in Economics and Finance, 2(1), 54-66. https://doi.org/10.22606/jaef.2017.21005

[50] Mohammed, I., \& Ehikioya, I. L. (2015). Macroeconomic Determinants of Economic Growth in Nigeria: A Cointegration Approach. International Journal of Academic Research in Economics and Management Sciences, 4(1), 156-175. https://doi.org/10.6007/ijarems/v4-i1/1485

[51] Mohammed, T., Retia, M., Gaidi, K., \& Boudeghdegh, A. (2018). The Impact of Exchange Rate Regimes on Economic Growth. 415-427. https://doi.org/10.1007/978-3-319-700557_33

[52] Mubarik, Y. A. (2005). Inflation and Growth: An Estimate of the Threshold Level of Inflation in Pakistan. In SBPResearch Bulletin (Vol. 1, Issue 1). http://www.pakistanbanks.org/career_deve lopment/am/downloads/bulletins/sbp_bulle tins/sbp_research_vol1_no1/Article-3.pdf

[53] Mugableh, M. I. (2018). Does Monetary Policy Affect Economic Growth in Jordan? Evidence from Ordinary Least Square Models. International Business Research, 12(1), 27. https://doi.org/10.5539/ibr.v12n1p27

[54] Munir, K., \& Qayyum, A. (2012). M P RA Measuring the effects of monetary policy in Pakistan: A factor augmented vector autoregressive approach Measuring the Effects of Monetary Policy in Pakistan: A Factor Augmented Vector Autoregressive
Approach. 35976. https://mpra.ub.unimuenchen.de/35976/

[55] Najaf, R. (2016). I S Monetary Policy Necessary for the Economic Development of Less Developed Countries with Special Reference to Pakistan. Business and Economics Journal, 08(01), 8-10. https://doi.org/10.4172/21516219.1000289

[56] Nwakoby, A. P. C. (2016a). Effect of Monetary Policy on Nigerian Stock Market Performanc. International Journal of Scientific Research and Management, May 2018.

https://doi.org/10.18535/ijsrm/v4i9.13

[57] Nwakoby, A. P. C. (2016b). Effect of Monetary Policy on Nigerian Stock Market Performanc. International Journal of Scientific Research and Management, April. https://doi.org/10.18535/ijsrm/v4i9.13

[58] Nwoko, N. M., Ihemeje, J., \& Anumadu, E. (2016). The impact of Monetary Policy on the economic growth of Nigeria. African Research Review, 10(3), 192. https://doi.org/10.4314/afrrev.v10i3.13

[59] Ononugbo, M. C. (2012). Monetary Policy in Developing Countries: The Case of Nigeria. July.

[60] Onyeagba, J. B. (2015). Monetary Policy and Economic Growth in Nigeria: A Critical Evaluation. IOSR Journal of Business and ManagementVer. II, 17(2), 2319-7668. https://doi.org/10.9790/487X1722110119

[61] Personal, M., \& Archive, R. (2011). Munich Personal RePEc Archive Impact of monetary policy on gross domestic product ( GDP ). 35562.

[62] Personal, M., \& Archive, R. (2017). Munich Personal RePEc Archive Dynamic Impact of Money Supply on Economic Growth in South Africa . An ARDL Approach. 82539.

[63] Pesaran, M. H., Shin, Y., \& Smith, R. J. (2001). Bounds testing approaches to the 
analysis of level relationships. Journal of Applied Econometrics, 16(3), 289-326. https://doi.org/10.1002/jae.616

[64] Precious, C., \& Palesa, M. K. (2014). Impact of monetary policy on economic growth: A case study of South Africa. Mediterranean Journal of Social Sciences, $5(15)$ 76-84. https://doi.org/10.5901/mjss.2014.v5n15p7 6

[65] Quartey, P. (2010). Price Stability and the Growth Maximizing Rate of Inflation for Ghana. Modern Economy, 01(03), 180194.

https://doi.org/10.4236/me.2010.13021

[66] Razmi, A., Rapetti, M., \& Skott, P. (2012). The real exchange rate and economic development. Structural Change and Economic Dynamics, 23(2), 151-169. https://doi.org/10.1016/j.strueco.2012.01.0 02

[67] Salian, G. (n.d.). Inflation and Economic Growth in India - An Empirical Analysis Prasanna V Salian 1, Gopakumar. K 2. Indian Econimice Serrvice . New Delhi, 128.

[68] Sanchez-Fung, J. R., \& Ghatak, S. (2006). Is fiscal policy sustainable in developing economies? In Review of Development Economics (Vol. 11, Issue 3).

[69] Sean, M. (2019). The Impact Of Monetary Policy On Economic Growth In Cambodia: Bayesian Approach. Economics, and Industrial Organization, 3(2), 16-34. https://doi.org/10.31039/jomeino.2019.3.2. 2

[70] Semuel, Hatane \& Nurina, S. (2015). Analysis of the Effect of Inflation, Interest Rates, and Exchange Rates on Gross Domestic Product ( GDP) in Indonesia. Proceedings of the International Conference on Global Business, Economics, Finance and Social Science, February, 20-22.

[71] Semuel, H. (2015). Analysis of the Effect of Inflation, Interest Rates, and Exchange
Rates on Gross Domestic Product (GDP ) in Indonesia. Proceedings of the International Conference on Global Business, Economics, Finance and Social Science, February, 20-22.

[72] Srithilat, K., \& Sun, G. (2017). The Impact of Monetary Policy on Economic Development : Evidence from Lao. Global Journal of Human-Social Science, 17(2), 816.

[73] State, O., Ifeakachukwu, N. P., State, O., Ditimi, A., \& State, O. (2012). A Trivariate Causality Test among Economic Growth , Government Expenditure and Inflation Rate : Evidence from. 3(1), 65-72.

[74] Sulaiman, L. A., \& Migiro, S. O. (2014). The nexus between monetary policy and economic growth in Nigeria: a causality test. Public and Municipal Finance, 3(2), $35-40$.

[75] The Asymmetric Effects of Monetary Policy: A Nonlinear Vector Autoregression Approach Author ( $\mathrm{s}$ ): Charles L . Weise Source: Journal of Money, Credit and Banking, Vol . 31, No . 1 ( Feb ., 1999 ), pp . 85-108 Published by: Ohio State University Pre. (2019). 31(1), 85-108.

[76] W. Madurapperuma, M. (2016). Impact of Inflation on Economic Growth in Sri Lanka. Journal of World Economic Research, $5(1), \quad 1$. https://doi.org/10.11648/j.jwer.20160501.1 1 